\title{
Ecological perspectives on variable retention forestry
}

\author{
Guillermo J. Martínez Pastur ${ }^{1 *}$, Ilkka Vanha-Majamaa² and Jerry F. Franklin ${ }^{3}$
}

\begin{abstract}
Forest management globally affects the ecosystem services, especially those related to ecosystem functioning and biodiversity conservation, by altering forest structure and composition. The degree of alteration was related to the intensity and type of harvesting; therefore, the major silvicultural challenge is to develop alternatives to mitigate climate change and maintain forest functions and biodiversity while also providing acceptable levels of timber production. Variable retention forestry (VRF) is a highly flexible concept, with continuity of forest cover, structure, function, and species composition, thereby supporting multiple economic, environmental, and cultural goals. This special issue provides an overview of the concepts and applications related to VRF implementation around the world. It shows that VRF has been applied globally for several decades, with varying levels and retention types, depending on local conditions and the economic importance of forestry. The challenges of VRF seem to differ to some extent on different continents, yet the general aims have been accepted in most of the continents. VRF has been successful in mitigating many effects of intensive harvesting, though in some forests of the world, the retention levels are too low to maintain acceptable levels of biodiversity and ecosystem functions. We conclude that an active collaboration between scientists and forest practitioners is needed to realize all of the opportunities provided by VRF in solving global forestry-related issues.
\end{abstract}

Keywords: Sustainable forestry, Biodiversity conservation, Timber production, Aggregated retention, Dispersed retention, Forest certification, Prescribed burning, Synergies and trade-offs

\section{Background}

Forests contain a major portion of the biodiversity inhabiting terrestrial ecosystems, and this diversity is positively correlated with the structural complexity of the forest ecosystem, including its spatial heterogeneity (Maguire et al. 2007). Although disturbances in forests can enhance diversity (Fedrowitz et al. 2014), increased disturbances are often the result of exotic species introduction (Soler et al. 2015, 2016). Additionally, silvicultural systems based on even-aged forest structures have resulted in forest landscapes that do not sustain the full array of forest functions typical of natural forest ecosystems or support their historical diversity (Lindenmayer et al. 2012; Lencinas et al. 2017; Gustafsson et al. 2020a). Forest management may not result in the levels of species extinction produced by more intensive land use

\footnotetext{
* Correspondence: gpastur@conicet.gov.ar

${ }^{1}$ Centro Austral de Investigaciones Científicas (CADIC), Consejo Nacional de Investigaciones Científicas y Técnicas (CONICET), Houssay 200 (9410),

Ushuaia, Tierra del Fuego, Argentina

Full list of author information is available at the end of the article
}

changes (e.g., deforestation for agriculture or urban development), but forest management practices can result in local species extinctions in the managed forested landscapes (Maguire et al. 2007; Hyvärinen et al. 2019). It can also result in significant reductions in other forest functions, such as hydrologic regulation (Franklin et al. 2018). Therefore, the main challenge in forestry is developing silvicultural systems that can provide economic timber production and regeneration of the managed stands, while simultaneously achieving social values and minimizing adverse effects on provision of ecosystem services, including biodiversity (Maguire et al. 2007; Perera et al. 2018).

Variable retention forestry (VRF) is a conceptual alternative to clear-cutting and even-aged management that can produce outcomes that integrate environmental, economic, and cultural goals. VRF is based upon the principle of retaining structural elements of the forest during regeneration harvesting for at least the next rotation in order to achieve specific management objectives 
(Franklin et al. 1997). The practice must incorporate two key elements: stable long-term structural diversity of harvesting units and a spatial distribution that maintains forest influence on the majority of the harvested area (Mitchell and Beese 2002). Life-boating of species is achieved by both sustaining pre-harvest forest structures (e.g., live trees, snags, and logs) that serve as important habitats for biota and structurally enriching the new developing forest stand (Beese and Bryant 1999; Maguire et al. 2007). The retained structures are the key retention elements needed to maintain biological diversity by both providing critical habitat to sustain forest species and by maintaining forest microclimatic conditions on the harvested unit (Arnott and Beese 1997; Franklin et al. 1997; Chen et al. 1999; Aubry et al. 1999; Lindenmayer et al. 2006; Fedrowitz et al. 2014; Gustafsson et al. 2020a). VRF has many goals, including maintaining some taxa characteristic of mature stands in the short-term, expediting recovery to pre-harvest conditions in the longer term, and retention of features that enhance the structural complexity of future stands (Franklin et al. 1997; Lindenmayer et al. 2006).

VRF has increasingly received social acceptance in recent years, due to its ability to meet a broader array of societal objectives. It has been applied to forests representing a wide range in composition and structure in diverse geographic locations and under different physical environments. Several long-term studies have provided evidence of its benefits, such as the Demonstration of Ecosystem Management Options (Aubry et al. 1999; Halpern et al. 1999); Montane Alternative Silvicultural Systems (Arnott and Beese 1997); Date Creek Silvicultural Systems (Coates and Burton 1997); Sicamous Creek Silvicultural Systems Research Project (Vyse 1999); Tanjil Bren Trial of the Warra Silvicultural Systems project (Hickey et al. 2001); projects MONTA, RETREE, DISTDYN and Effaråsen (Vanha-Majamaa and Jalonen 2001; Matveinen-Huju et al. 2006; Koivula et al. 2014; Djupström and Weslien 2019); PEBANPA network (Peri et al. 2016); and more recently ConFobi project (Asbeck et al. 2019; Gustafsson et al. 2020a).

Retention may be implemented as either individual or small groups of structures (e.g., living trees and snags) dispersed through the harvest unit, which is known as dispersed retention (DR), or as patches of intact forest known as aggregated retention (AR). AR varies according to the management objectives but it typically involves patches that are a minimum of a quarter of a hectare in size since one goal of the retention system is to retain spatial heterogeneity (Mitchell and Beese 2002). However, in Fennoscandia, they are much smaller and consist of only a couple of individual trees (e.g., Kuuluvainen et al. 2019). The level of DR ranges from a low of $5 \%$ of the pre-treatment basal area in the Montane Alternative
Silvicultural Systems, to a high of $70 \%$ of the pretreatment volume at Date Creek Silvicultural Systems (Arnott and Beese 1997; Coates and Burton 1997; Aubry et al. 1999; Vyse 1999; Halpern et al. 1999; Hickey et al. 2001). In experimental studies in Fennoscandia, DR has varied accordingly from $2-3 \%$ up to $70 \%$ of retention (Vanha-Majamaa et al. 2007; Kouki 2019). In southern Patagonia (Argentina), 30\% of the primary forests are left as AR (Martínez Pastur et al. 2009; Lencinas et al. 2017), which was also the approach in the Warra Silvicultural Systems trial for wet Eucalyptus obliqua forests in Tasmania (Hickey et al. 2001). In the Pacific Northwest of North America, the retained patches are often 0.1-1.0 ha in size (Franklin et al. 1997). In the Demonstration of Ecosystem Management Options (Aubry et al. 1999; Halpern et al. 1999) study, $15 \%$ and $40 \%$ of AR treatments consisted of circular 1.0 ha undisturbed patches retained within the treatment units. This was also the case in the Montane Alternative Silvicultural Systems (Arnott and Beese 1997). Combining both dispersed and aggregated retention provides the ecological benefits of both approaches. This has been done in southern Patagonia (Argentina), where $10-15 \mathrm{~m}^{2} \mathrm{ha}^{-1}$ of basal area was left as DR in the harvested areas between the aggregates (Martínez Pastur et al. 2009). This is also a common practice in the applications in northwestern North America, such as federal forest lands in Oregon (Franklin et al. 1997). A comparison of these long-term studies and the benefits of the outputs to achieve sustainable forestry around the world have been discussed by Gustafsson et al. (2012) and Lindenmayer et al. (2012).

\section{Ecological perspectives on VRF}

Maintaining the biological diversity and other ecosystem services of pristine forests requires more than the prevention of their conversion to agriculture or plantations or simply creating protected areas. It is also necessary to maintain structural complexity in actively managed forests by using harvest practices that will maintain biodiversity and ecosystem functions. VRF is based upon the concept of retaining structural elements of the harvested stand for at least the next rotation in order to achieve specific management objectives. New applications of this approach are being developed and used around the world currently. It is for this reason we developed this special globally oriented issue to report on the ecological effects of VRF. Our intention is to illustrate the diversity of the applications and ecological consequences of VRF management in forests around the world, which integrate environmental, cultural, and economic objectives. The collection of the articles presented here describe new concepts of VRF and the results of short- and long-term research projects in VRF by both private and governmental sector forest organizations. 
The importance of conceptual clarity in the development of scientific knowledge and its application in management and policy is emphasized by Galetto et al. (2019). In this sense, decision-making includes a hierarchy of values, beliefs, and perspectives, which may come into conflict between different social actors. For example, a particular criterion for VRF may be to achieve good yields with a reasonable conservation management in some regions of the world. However, to be acceptable in a particular region, it is helpful to clarify the range of possibilities for VRF application. The presented material shows how VRF has been implemented around the world during the last several decades to successfully meet different management and conservation objectives.

\section{VRF in North America}

VRF was first proposed in North America (e.g., for Pseudotsuga menziesii forests in the Pacific Northwest region) in response to increasing dissatisfaction with the ecological consequences of clear-cutting, particularly its failure to provide adequate wildlife habitat and fulfill other important forest functions (Franklin and Donato 2020). The history and current application of VRF on forests in western Washington and Oregon (USA) are described in this article, which is where many basic VRF concepts were first developed and implemented. This history is a good starting point for understanding the advantages and trade-offs involved in the VRF concept, depending upon the different relevant ecological and socio-economic factors. The implementation of VRF in forests with mixedseverity disturbance regimes (Pinus resinosa dominated forests of the western Great Lakes region) is described by Palik and D'Amato (2019), where disturbances commonly result in only partial mortality of canopy trees in spatially heterogeneous patterns. The importance of having a comprehensive understanding of the natural pattern of forest development is made clear in this article, including different severity disturbance regimes in developing a specific VRF application. Two decades of VRF implementation in British Columbia are reported by Beese et al. (2019), which emphasizes the effectiveness of the approach for biodiversity conservation. These three North American reviews illustrate how both $\mathrm{AR}$ and $\mathrm{DR}$ contribute to biodiversity conservation by providing short-term life-boating habitat for some species and by enhancing the structural characteristics of the future stands. Also, some trade-offs are identified, such as some reductions in timber production as a result of wind damage to retained trees and reduced growth rates of tree regeneration compared to clear-cuts.

\section{VRF in Australia}

VRF was proposed in Australia (mainland and Tasmania) as one alternative to recover and maintain some ecological values in the managed stands, which experienced significant decreases in the local fauna following clear-cutting. There was a general social acceptance of this modification of traditional harvesting. Lindenmayer et al. (2019) review its use in the State of Victoria's Mountain Ash (Eucalyptus regnans) forests in the mainland (southeastern Australia). An experiment established in 2003 has provided environmental benefits it provided for some groups of small mammals, birds, and vascular plants and the long-term monitoring program associated with it. The challenge in protecting AR during prescribed post-harvesting regeneration burns is also described. A conclusion of this research is that VRF has the potential to contribute to biodiversity conservation in Mountain Ash forests. Scott et al. (2019) summarizes results of over 16 years of monitoring of VRF in Tasmania, primarily in AR. As on mainland Australia, the main challenge was the prescribed post-harvesting regeneration burns and the preferred solution to use of edge aggregates instead of isolated retained islands of AR. The authors conclude that VR using edge aggregates provides clear biodiversity benefits and satisfactory silvicultural outcomes, thereby providing a viable alternative to clear-cuts in Tasmanian wet eucalypt forests.

\section{VRF in Northern Europe}

Modern silviculture was largely developed in Central and Northern Europe beginning in the 1800s to fulfill the needs of energy in industry, resulting in the rapid conversion of pristine forests into intensively managed stands. For example, in Fennoscandia, clear-cuts seem to have started in Russia (Shorohova et al. 2019) in 1910, but Finland and Sweden's mainly selective fellings were carried out until the 1950s when clear-cuts started to replace them. The common practice in clear-cuts since has been using site preparation and planting but with initial tree species, mainly Scots pine (Pinus sylvestris) and Norway spruce (Picea abies). During the last few decades, an increasing social concern about the negative effects of clear-cuts to biodiversity has made ecosystem services provisions encourage the creation and implementation of new silvicultural approaches; however, clear felling is still the prevailing method in final-cuts. In this sense, retention of individual trees in harvested compartments started in the 1980s, followed by forest certification criteria defining the currently used minimum number of ten retained trees per hectare. VRF has become an approach to try to reconcile the often conflicting goals of timber production, provision of other ecosystem services, and safeguarding of biodiversity. However, the retention levels are very low. 
Five papers are included in this review on applications of VRF in Northern Europe. Two of the papers are focused solely on Finland. Kuuluvainen et al. (2019) show that the total volume of living retention is currently less than $3 \mathrm{~m}^{3} \mathrm{ha}^{-1}$ and make the additional criticism that total volumes of retention have been further reduced on final-cuts in recent years. They argue that this is ecologically far too low a level of retention and that the aim has been to use the lowest level of retention that will allow market access and not to use ecological knowledge to attain specific ecological sustainability goals. Lindberg et al. (2020) describe that in Finland, the annually burned area in forest fires has diminished in recent decades due to effective fire prevention, suppression, and intensive forestry. They show that this has led to a decline of fire-adapted habitat types and species, many of which have become red-listed. They recommend several actions to improve the situation with fire-dependent biodiversity and to combine prescribed burning with variable retention harvesting to better mimic natural disturbance dynamics. In a third paper, Shorohova et al. (2019) discuss the first use of variable retention forestry in European boreal forests in Russia, which had already begun in 1910. These harvests involved remarkable amounts of retention, such as $10-40 \%$ of the tree volume. This VR applied during the last century has emulated natural disturbances and created diverse unevenaged forest structures with large amounts of diverse coarse woody debris. They point out that the long time period of clear felling, but with high retention levels, would provide a unique possibility to evaluate the longterm impacts of VRF on biodiversity and forest dynamics.

Finally, two last papers discuss VRF throughout Fennoscandia, including the Baltic region. Gustafsson et al. (2020b) present results from a systematic search of the retention literature, separated into the following topics: buffer zones, retention patches, high stumps, other types of dead wood, and cost efficiency. They conclude that retention patches as large as $0.6 \mathrm{ha}$ and $10 \mathrm{~m}$ wide buffers to watercourses are not enough to maintain pre-harvest species composition but survival of forest species is still larger than on conventional clear-cuts. Finally, they identify several important future research directions for VRF, including a switch of focus towards the landscape as well as the species population level. In the last paper, Koivula and Vanha-Majamaa (2020) review experimental results from 22 replicated experiments on the effects of variable retention and two restoration measures (prescribed burning and artificial addition of coarse woody debris) on different species groups in Fennoscandia. They show that $50-70 \%$ retention of the initial tree volume would be necessary to prevent changes in the species composition associated with shady conditions. The negative effects of harvesting remain detectable for at least 10-15 years or even up to 100 years. They conclude that no logging method per se supports specialized and threatened forest species, although retention mitigates many negative effects. Maintenance and active increase of legacies, such as deadwood in all decay classes, microclimatic continuity, as well as retaining very old trees and tree-species mixtures, are required.

\section{VRF in South America}

This special issue includes three papers on VRF in South America, particularly in Argentina. Martínez Pastur et al. (2019) synthesize the main outputs of its implementation in Nothofagus pumilio forests in Southern Patagonia, including sawmill operations, timber yield, overstory stability, forest structure, microclimate and natural cycles, natural regeneration dynamics, and biodiversity (mammals, understory plants, mistletoes, birds, arthropods, mosses, lichens, and fungi). In general, AR maintained forest structure and microenvironmental variables and slightly increased biodiversity and forest reproduction variables compared to unmanaged primary forests. On the contrary, DR decreased forest structure variables and greatly increased biodiversity. Based on this, a combination of both retention types (AR and DR) was preferred and implemented at large scale in Tierra del Fuego (Argentina). The authors conclude that VRF has been a useful tool to conserve biodiversity and ecosystem functions, approaching to the balance between economy, ecology, and social requirements in the managed areas.

Toro Manríquez et al. (2019) focus on the natural regeneration of Nothofagus pumilio in the different microenvironments created by VRF. Microenvironments offered different environmental conditions for natural regeneration. Increasing the most favorable environments for regeneration improved the recruitment, growth, and eco-physiological performance of the seedlings after harvesting. This information can help in designing VRF prescriptions that increase favorable microsite conditions and decrease unfavorable microenvironments, improving regeneration success. Cavallero et al. (2019) describe the benefits of retention and distribution of biological legacies, which can generate resource sinks in silvopastoral systems of Arid Chaco forests. Implementations of VRF are usually in temperate forests harvested for timber with a few studies in other forest systems (e.g., subtropical or tropical forests) with other management objectives (e.g., silvopastoral). The examples in this paper are innovative in expanding the potential uses of VRF around the world. The inclusion of different woody structures in the managed stands decreased the sediment and litter loss in the short term and helped reconstitute the structure and composition of the forest community in the long term. They 
conclude that incorporating biological legacies at strategic locations can be a useful and relatively cost-free retention practice for multipurpose forest management and conservation strategies.

\section{Final remarks}

VRF has been implemented in a wide range of forest types, eco-regions, socio-economic conditions, and countries all over the world. The long-term studies presented here illustrated the effectiveness of VRF in conserving ecological functions and biodiversity values, thereby sustaining many ecosystem services in the managed forests. The effectiveness of retention in maintaining ecosystem services, especially biodiversity, is directly related to the type and level of retention, which is determined by the management and conservation objectives. The VRF article collection presented here provides an update of its implementation around the world and includes many examples of new applications that illustrate its potential in different forest types and social contexts. Our intent is to help researchers and managers to see new opportunities in the application of VRF, thereby acting as a bridge between science and practice and between the forest industry and the societies in which it is embedded.

\section{Abbreviations}

AR: Aggregated retention; DR: Dispersed retention; VRF: Variable retention forestry

\section{Acknowledgements}

We wish to thank all authors in this special issue, the Journal, and especially Jiquan Chen for the support of this initiative.

\section{Authors' contributions}

GMP had the initial idea of the special issue of the topic. All authors collaborated in an equal manner in writing the manuscript. All authors read and approved the final manuscript

\section{Authors' information}

No additional information

\section{Funding}

Nothing to inform

\section{Availability of data and materials \\ Nothing to inform}

Ethics approval and consent to participate

No ethics or conflict of interest exists.

\section{Consent for publication}

The authors consent to publish the data included in this draft.

\section{Competing interests}

The authors declare that they have no competing interests.

\section{Author details}

${ }^{1}$ Centro Austral de Investigaciones Científicas (CADIC), Consejo Nacional de Investigaciones Científicas y Técnicas (CONICET), Houssay 200 (9410), Ushuaia, Tierra del Fuego, Argentina. ${ }^{2}$ Natural Resources Institute Finland (Luke), Latokartanonkaari 9, Fl-00790 Helsinki, Finland. ${ }^{3}$ School of Environmental and Forest Science, University of Washington, Seattle, WA 98195, USA.
Received: 9 January 2020 Accepted: 9 January 2020

Published online: 19 February 2020

\section{References}

Arnott JT, Beese WJ (1997) Alternatives to clearcutting in British Columbia coastal montane forests. Forest Chron 73:670-678

Asbeck T, Pyttel P, Frey J, Bauhus J (2019) Predicting abundance and diversity of tree-related microhabitats in Central European montane forests from common forest attributes. For Ecol Manag 432:400-408

Aubry KB, Amaranthus M, Halpern C, White J, Woodard B, Peterson C, Lagoudakis C, Horton A (1999) Evaluating the effects of varying levels and patterns of green tree retention: experimental design of the DEMO study. Northwest Sci 73:12-26

Beese WJ, Bryant AA (1999) Effect of alternative silvicultural systems on vegetation and bird communities in coastal montane forests of British Columbia, Canada. For Ecol Manag 115:231-242

Beese WJ, Deal J, Dunsworth G, Mitchell SJ, Philpott TJ (2019) Two decades of variable retention in British Columbia: a review of its implementation and effectiveness for biodiversity conservation. Ecol Proc 8:33

Cavallero L, Ledesma M, López DR, Carranza C (2019) Retention and redistribution of biological legacies generate resource sinks in silvopastoral systems of Arid Chaco forests. Ecol Proc 8:27

Chen J, Saunders SC, Crow TR, Naiman RJ, Brosofske KD, Mroz GD, Brookshire BL, Franklin JF (1999) Microclimate in forest ecosystem and landscape ecology: variations in local climate can be used to monitor and compare the effects of different management regimes. BioScience 49:288-297

Coates KD, Burton PJ (1997) A gap-based approach for development of silvicultural systems to address ecosystem management objectives. For Ecol Manag 99:337-354

Djupström L, Weslien J (2019) Effaråsen - att bruka och bevara i gammal tallskog. SkogForsk Arbetsrapport:1009-2019 31 pp (in Swedish)

Fedrowitz K, Koricheva J, Baker SC, Lindenmayer DB, Palik B, Rosenvald R, Beese W, Franklin JF, Kouki J, Macdonald E, Messier C, Sverdrup-Thygeson A, Gustafsson L (2014) Can retention forestry help conserve biodiversity? A meta-analysis. J Appl Ecol 51:1669-1679

Franklin JF, Berg DR, Thornburgh DA, Tappeiner JC (1997) Alternative silvicultural approaches to timber harvesting. In: Kohm KA, Franklin JF (eds) Creating a forestry for the $21^{\text {st }}$ century: the science of ecosystem management. Island Press, Washington DC, pp 111-139

Franklin JF, Donato DC (2020) Variable retention harvesting in the Douglas-fir region. Ecol Proc 9:8

Franklin JF, Johnson KN, Johnson DL (2018) Ecological Forest Management. Waveland Press, Long Grove, p 646

Galetto L, Torres C, Martínez Pastur G (2019) Variable retention harvesting: conceptual analysis according to different environmental ethics and forest valuation. Ecol Proc 8:40

Gustafsson L, Baker SC, Bauhus J, Beese WJ, Brodie A, Kouki J, Lindenmayer DB, Löhmus A, Martínez Pastur G, Messier C, Neyland M, Palik B, SverdrupThygeson A, Volney WJA, Wayne A, Franklin JF (2012) Retention forestry to maintain multifunctional forests: a world perspective. BioScience 62:633-645.

Gustafsson L, Bauhus J, Asbeck T, Augustynczik ALD, Basile M, Frey J, Gutzat F, Hanewinkel M, Helbach J, Jonker M, Knuff A, Messier C, Penner J, Pyttel P, Reif A, Storch F, Winiger N, Winke G, Yousefpour R, Storch I (2020a) Retention as an integrated biodiversity conservation approach for continuous-cover forestry in Europe. Ambio 49:85-97

Gustafsson L, Hannerz M, Koivula M, Shorohova E, Vanha-Majamaa I, Weslien 」 (2020b) Research on retention forestry in Northern Europe. Ecol Proc 9:3

Halpern CB, Evans SA, Nelson CR, McKenzie D, Liquori D, Hibbs D, Halal MG (1999) Response of forest vegetation to varying levels and patterns of greentree retention: an overview of a long-term experiment. NW Sci 73:27-44

Hickey JE, Neyland MG, Bassett OD (2001) Rationale and design for the Warra silvicultural systems trial in wet Eucalyptus obliqua forests in Tasmania. Tasforests 13:155-182

Hyvärinen E, Juslén A, Kemppainen E, Uddström A, Liukko UM (2019) The 2019 red list of Finnish species. Ministry of Environment and Finnish Environment Institute, Helsinki, p 703

Koivula M, Kuuluvainen T, Hallman E, Kouki J, Siitonen J, Valkonen S (2014) Forest management inspired by natural disturbance dynamics (DISTDYN) - a long-term research and development project in Finland. Scand J For Res 29:579-592 
Koivula M, Vanha-Majamaa I (2020) Experimental evidence on ecological impacts of retention forestry, prescribed burning and deadwood manipulation in Fennoscandia. Ecol Proc. In press

Kouki J (2019) Fire and retention trees in facilitating biodiversity in boreal forests. http://forest.uef.fi/jarikouki/project_fire.htm

Kuuluvainen T, Lindberg H, Vanha-Majamaa I, Keto-Tokoi P, Punttila P (2019) Lowlevel retention forestry, certification and biodiversity: case Finland. Ecol Proc 8:47

Lencinas MV, Sola F, Martínez Pastur G (2017) Variable retention effects on vascular plants and beetles along a regional gradient in Nothofagus pumilio forests. For Ecol Manag 406:251-265

Lindberg H, Punttila P, Vanha-Majamaa I (2020) The challenge of combining variable retention and prescribed burning in Finland. Ecol Proc 9:4

Lindenmayer D, Blair D, McBurney L (2019) Variable retention harvesting in Victoria's Mountain Ash (Eucalyptus regnans) forests (southeastern Australia). Ecol Proc 8:2

Lindenmayer DB, Franklin JF, Fischer J (2006) General management principles and a checklist of strategies to guide forest biodiversity conservation. Biol Conserv 131:433-445

Lindenmayer DB, Franklin JF, Lõhmus A, Baker SC, Bauhus J, Beese W, Brodie A Kiehl B, Kouki J, Martínez Pastur G, Messier C, Neyland M, Palik B, SverdrupThygeson A, Volney J, Wayne A, Gustafsson L (2012) A major shift to the retention approach for forestry can help resolve some global forest sustainability issues. Conserv Lett 5:421-431

Maguire DA, Halpern CB, Phillips DL (2007) Changes in forest structure following variable-retention harvests in Douglas-fir dominated forests. For Ecol Manag 242:708-726

Martínez Pastur G, Lencinas MV, Cellini JM, Peri PL, Soler R (2009) Timber management with variable retention in Nothofagus pumilio forests of Southern Patagonia. For Ecol Manag 258:436-443

Martínez Pastur G, Rosas YM, Toro Manríquez MDR, Huertas Herrera A, Miller JA, Cellini JM, Barrera MD, Peri PL, Lencinas MV (2019) Knowledge arising from long-term research of variable retention harvesting in Tierra del Fuego: where do we go from here? Ecol Proc 8:24

Matveinen-Huju K, Niemelä J, Rita H, O'Hara RB (2006) Retention-tree groups in clear-cuts: do they constitute 'life-boats' for spiders and carabids? For Ecol Manag 230:119-135

Mitchell SJ, Beese WJ (2002) The retention system: reconciling variable retention with the principles of silvicultural systems. For Chron 78:397-403

Palik BJ, D'Amato AW (2019) Variable retention harvesting in Great Lakes mixed-pine forests: emulating a natural model in managed ecosystems. Ecol Proc 8:16

Perera A, Peterson U, Martínez Pastur G, Iverson L (2018) Ecosystem services from forest landscapes: broadscale considerations. Springer, Cham. 265 p.

Peri PL, Lencinas MV, Bousson J, Lasagno R, Soler R, Bahamonde H, Martínez Pastur G (2016) Biodiversity and ecological long-term plots in southern Patagonia to support sustainable land management: the case of PEBANPA network. J Nat Conserv 34:51-64

Scott RE, Neyland MG, Baker SC (2019) Variable retention in Tasmania, Australia: trends over 16 years of monitoring and adaptive management. Ecol Proc 8:23

Shorohova E, Sinkevich S, Kryshen A, Vanha-Majamaa I (2019) Variable retention forestry in European boreal forests in Russia. Ecol Proc 8:34

Soler R, Schindler S, Lencinas MV, Peri PL, Martínez Pastur G (2015) Retention forestry in southern Patagonia: multiple environmental impacts and their temporal trends. Int For Rev 17:231-243

Soler R, Schindler S, Lencinas MV, Peri PL, Martínez Pastur G (2016) Why biodiversity increases after variable retention harvesting: a meta-analysis for southern Patagonian forests. For Ecol Manag 369:161-169

Toro Manríquez MDR, Cellini JM, Lencinas MV, Peri PL, Peña Rojas KA, Martínez Pastur G (2019) Suitable conditions for natural regeneration in variable retention harvesting of southern Patagonian Nothofagus pumilio forests. Ecol Proc 8:18

Vanha-Majamaa I, Jalonen J (2001) Green tree retention in Fennoscandian forestry. Scand J For Res Suppl 3:79-90

Vanha-Majamaa I, Lilja S, Ryömä R, Kotiaho JS, Laaka-Lindberg S, Lindberg H, Puttonen P, Tamminen P, Toivanen T, Kuuluvainen T (2007) Rehabilitating boreal forest structure and species composition in Finland through logging, dead wood creation and fire: the EVO experiment. For Ecol Manag 250:77-88

Vyse A (1999) Is everything all right up there? A long-term interdisciplinary silvicultural systems project in a high elevation fir-spruce forest at Sicamous Creek BC. For Chron 75:467-472

\section{Publisher's Note}

Springer Nature remains neutral with regard to jurisdictional claims in published maps and institutional affiliations.

\section{Submit your manuscript to a SpringerOpen ${ }^{\circ}$ journal and benefit from:}

- Convenient online submission

- Rigorous peer review

- Open access: articles freely available online

- High visibility within the field

- Retaining the copyright to your article

Submit your next manuscript at $\boldsymbol{\nabla}$ springeropen.com 